\title{
Газовый волоконный рамановский лазер с высокой средней мощностью излучения на длине волны 4,4 мкм
}

\author{
М.С. Астапович $^{1}$, А.Н. Колядин ${ }^{1}$, М.М. Худяков ${ }^{1,2}$, А.В. Гладышев ${ }^{1, *}$, \\ А.Ф. Косолапов ${ }^{1}$, М.Е. Лихачев ${ }^{1}$, И.А. Буфетов ${ }^{1}$ \\ ${ }^{1}$ Научный центр волоконной оптики РАН \\ ${ }^{2}$ Московский физико-технический институт (государственный университет) \\ "E-mail: alexglad@fo.gpi.ru
}

DOI:10.31868/RFL2018.86-87

Газовые волоконные лазеры на основе световодов с полой сердцевиной (CПС) перспективны для создания эффективных генераторов излучения среднего ИК диапазона. Активной средой таких лазеров является газ, заполняющий сердцевину СПС и обладающий дипольно-активными или комбинационноактивными переходами. При этом сильная локализация оптического излучения в полой сердцевине не только способствует эффективному взаимодействию излучения с активной средой, но и позволяет работать в среднем ИК диапазоне на длинах волн вплоть до 5 мкм даже при использовании СПС, оболочка которых изготовлена из кварцевого стекла [1].

Применение кварцевых СПС револьверного типа позволило недавно реализовать лазеры среднего ИК диапазона на основе вынужденного комбинационного (рамановского) рассеяния (ВКР) в молекулярном водороде [24]. Используя в качестве источника накачки наносекундный эрбиевый волоконный лазер $(\lambda=1,56$ мкм), была достигнута ВКР-генерация на длине волны 4,4 мкм со средней мощностью 250 мВт и квантовой эффективностью $36 \%[4]$.

a)

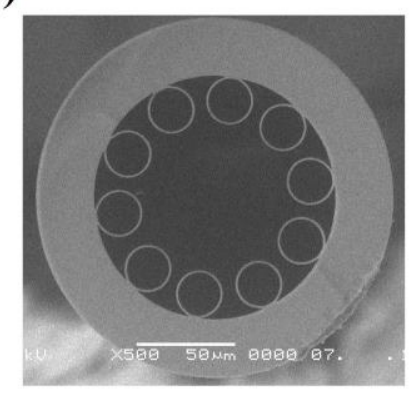

б)

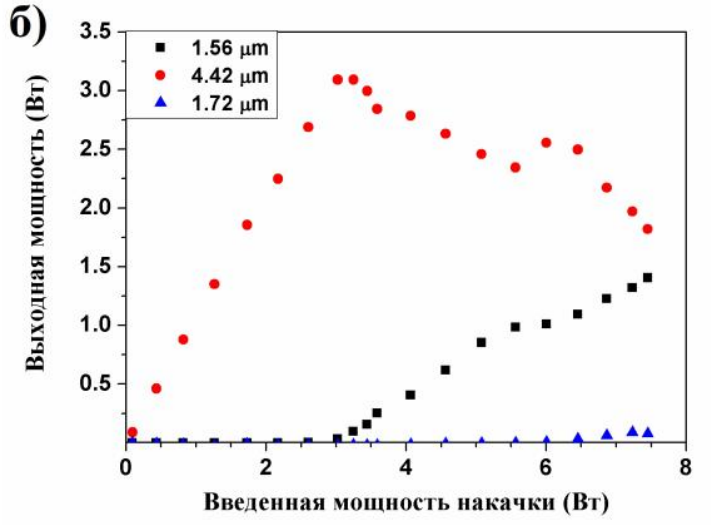

Рис.1. (а) Микрофотография поперечного сечения револьверного световода. Диаметр полой сердцевины составляет 75 мкм. (б) Зависимости средней выходной мощности ВКР-лазера от средней мощности накачки, введенной в полую сердцевину. Представленные зависимости соответствуют непреобразованной накачке $\lambda=1,56$ мкм (красные точки), колебательной стоксовой компоненте $\lambda=4,42$ мкм (черные квадраты) и вращательной стоксовой компоненте $\lambda=$ 1,72 мкм (синие треугольники).

Целью данной работы является повышение эффективности и средней выходной мощности газового волоконного ВКР-лазера с длиной волны генерации 4,4 мкм, представленного раннее в [4]. Путем уменьшения спектральной ширины излучения лазера накачки нам удалось повысить квантовую эффективность ВКРлазера до теоретического предела для ВКР-преобразования 1,56 $\rightarrow$ 4,4 мкм в наносекундном режиме. Кроме того, увеличение средней мощности лазера 
накачки позволило более чем в 5 раз повысить среднюю выходную мощность ВКР-лазера на длине волны 4,4 мкм.

Газовый волоконный ВКР-лазер был собран по типовой схеме, представленной в [2]. В качестве задающего осциллятора использовался одночастотный полупроводниковый лазер с распределенной обратной связью ( $\lambda=1,56$ мкм, ширина линии 2 МГц). В предыдущих работах оптические импульсы формировались путем прямой модуляции задающего осциллятора током накачки, что приводило к уширению линии генерации до 0,1 нм. Это значение является достаточно большим и может приводить к снижению эффективности ВКР в газах, поэтому в данной работе мы применили новую схему формирования оптических импульсов. Излучение задающего осциллятора, работающего в непрерывном режиме, подавалось на полупроводниковый оптический усилитель. Оптические импульсы формировались путем модуляции тока питания этого усилителя внешним генератором. Затем излучение усиливалось в трех каскадах волоконных эрбиевых усилителей. Данная схема позволила уменьшить спектральную ширину излучения лазера накачки до значений не более 0,02 нм, что соответствует спектральному разрешению измерительной аппаратуры.

Кроме того, мощность накачки ( $\lambda=0,98$ мкм) и длина активного световода третьего каскада усиления волоконного эрбиевого лазера также были увеличены, что привело к повышению средней выходной мощности лазера накачки на длине волны 1,56 мкм до 10 Вт. При этом пиковая мощность излучения на длине волны 1,56 мкм составляла 24 кВт, а частота повторения и длительность импульсов равнялись 190 кГц и 2,2 нс, соответственно.

Излучение волоконного эрбиевого лазера накачки $(\lambda=1,56$ мкм) с помощью линз вводилось в кварцевый револьверный световод (рис. 1а), аналогичный по своим характеристикам световоду, применявшемуся в работе [4]. Диаметр полой сердцевины составлял 75 мкм, что соответствует диаметру поля основной моды 55 мкм. Длина световода равнялась 3,5 м. Концы световода герметизировались в миниатюрных газовых ячейках, а полая сердцевина заполнялась молекулярным водородом под давлением 50 атм при комнатной температуре.

В результате проведенной оптимизации квантовая эффективность ВКРлазера на длине волны 4,4 мкм была повышена до 53 \%, что практически соответствует теоретическому пределу (55\%) для ВКР-преобразования наносекундных импульсов в молекулярном водороде. Кроме того, средняя выходная мощность стоксовой компоненты на длине волны 4,4 мкм достигла 1,4 Вт (рис. 1б), что более чем в 5 раз превосходит опубликованные ранее значения и демонстрирует перспективность газовых волоконных ВКР-лазеров, как источников излучения среднего ИК диапазона.

Работа выполнена при финансовой поддержке Российского научного фонда (грант №16-19-10513).

\section{Литература}

[1] C. Wei, R. J. Weiblen et al., Adv. Opt. Photon., 9, 504-561 (2017)

[2] A.V. Gladyshev, A.F. Kosolapov et al., IEEE J. Sel. Top. Quantum Electron., 24, 0903008 (2018)

[3] А. В. Гладышев, А. Ф. Косолапов и др., Квантовая электроника, 47(5), 491-494 (2017)

[4] А. В. Гладышев, А. Ф. Косолапов и др., Квантовая электроника, 47(12), 1078-1082 (2017) 